\title{
Simple Bone Cyst of the Anterior Mandible: A Case Report
}

\author{
Rattana-arpha Pornpop* \\ Dentistry Division, Bhumibol Adulyadej Hospital, Thailand
}

Submission: August 14, 2017; Published: August 21, 2017

*Corresponding author: Rattana-arpha Pornpop, Dentistry Division, Bhumibol Adulyadej Hospital, 171 Phaholyothin Road, Klongtanon, Saimai, Bangkok, Thailand, Email: questionnice@gmail.com

\begin{abstract}
Simple bone cyst is a benign pseudo cystic cavity in the bone that is either empty or contains fluid. It is an uncommon disorder of the jaw bones as well as the other skeletal bones, particularly the long bones. The body of the mandible is the most common site of the jaw bones. Its onset occurs mainly during the first two decades of life. This article will describe the case of a SBC located in the anterior mandible of a 15 years old female patient including clinical, radiographic, histopathologic features and its treatment.
\end{abstract}

Keywords: Simple bone cyst; Anterior mandible; Differential diagnosis

\section{Introduction}

Simple bone cyst (SBC) was first recognized by Lucas \& Blum in 1929 [1]. Blum reported the first three cases in dentistry in 1932 [2]. It has been identified with many names such as solitary bone cyst, traumatic bone cyst, hemorrhagic bone cyst, unicameral bone cyst, progressive bone cavity, extravasation cyst, primary bone cyst and idiopathic bone cavity [3]. Trauma is the most frequently discussed about its etiologic factor in the formation of SBC. Most of SBC are diagnosed incidentally in panoramic radiograph and most of the individuals affected are in teens [4]. Radiographically, it manifests as a well-defined unilocular, radiolucency which occasionally presents a typical festooned pattern around the apices of the adjacent teeth $[5,6]$. Definite diagnosis of SBC is inevitably reached during surgery when a cavity lacing epithelial lining is either empty or with content or filled with serous or sanguineous fluids [6]. This report describes a rare SBC case of anterior mandible with incidental finding from panoramic radiograph.

\section{Case Report}

A 15 years old female was referred to the clinic by a general dentist for evaluation of an asymptomatic radiolucent lesion located in the anterior mandible. The medical history was not contributed and she could not recall a history of trauma. Extraand intraoral examinations revealed no abnormal findings. The lower anterior teeth were not mobile and positive for the vitality tests. No palpable lymph node was presence.

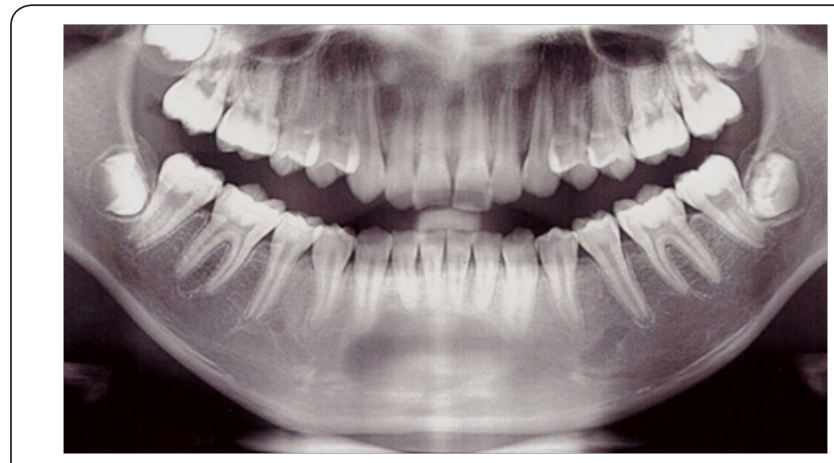

Figure 1: Radiological examination: Cropped panoramic film reveals a well-defined unilocular radiolucency in the anterior mandible.

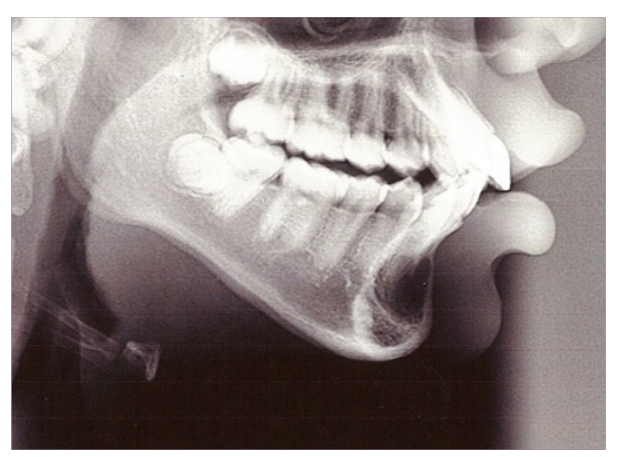

Figure 2: Radiological examination: Cropped lateral cephalometric film reveals mild labial expansion with thin labial cortex. 
Panoramic radiograph revealed a well-defined unilocular radiolucent area of size $2 \times 3.5 \mathrm{~cm}$ extending from inferior aspect of the roots of lower right canine to lower left canine (Figure 1 \& 2). The inferior border of the mandible was not affected. The lateral cephalometric radiograph revealed a mild labial expansion with a thin labial cortex. The radiographic differential diagnosis comprised odontogenic keratocyst, unicystic ameloblastoma, central giant cell granuloma and SBC.
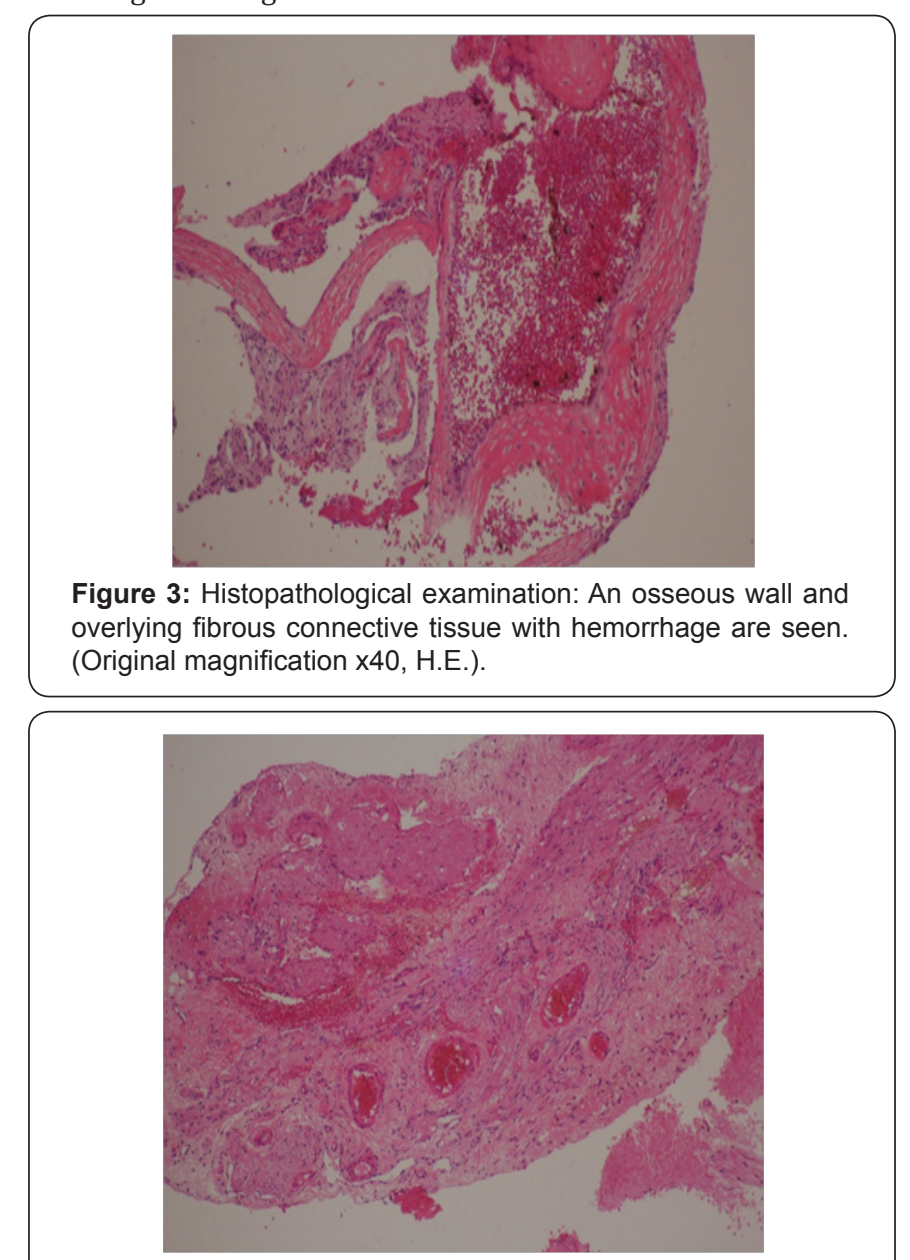

Figure 4: Histopathological examination: A strip of fibrous connective tissue with congested blood vessels is present. (Original magnification $\times 100$, H.E.).

Under local anesthesia, a biopsy was performed before the determination of the definitive treatment. On surgical exploration, the lesion was found to be an empty cavity, with no evidence of epithelial lining or tumoral tissue, and contained small amount of fluid mixed with blood. The operative findings were suggestive of SBC; therefore, curettage of the cavity was performed. The removed pieces of bone with minimal amount of soft tissue were sent for histopathological examination. Histopathologically, the section revealed thin strips of osseous wall and overlying fibrous connective tissue with no epithelial lining (Figure 3 \& 4). Extravasated erythrocytes and congested blood vessels were also seen. On the basis of clinical, radiological and histopathological findings, thus, a final diagnosis of SBC was made. The postoperative recovery was uneventful and the complete healing was observed one year later.

\section{Discussion}

The SBC is an uncommon non epithelial-lined cavity of the jaws, found mainly in young patients [7]. Most of them are found in the posterior mandible between the canine and the third molar followed by the mandibular symphysis [7]. Clinically, the lesion is generally asymptomatic and is often incidentally discovered during routine radiological examination [4]. Pain is infrequent and presents in $10 \%$ to $30 \%$ of patients [8]. Radiographically, the SBC generally shows up as unilocular radiolucency, which its margins are characteristically scalloped among dental roots $[4,7,9,10]$. Definitive diagnosis of SBC is done with surgery when an empty space without epithelial lining is observed, with very little amount of fluid $[8,10]$. Associated conditions such as cement-osseous dysplasia and fibrous dysplasia were reported and it seemed to be occur in the older patients $[11,12]$.

In this present case, the patient was a young female without any symptoms. The age, the clinical finding and the site of the lesion led the clinician to suspect benign lesion. Radiographic features of this case can be confused with a wide variety of odontogenic and non-odontogenic radiolucent lesions of the anterior lower jaw such as the unicystic ameloblastoma, odontogenic keratocyst, glandular odontogenic cyst and central giant cell granuloma. Therefore, a surgical exploration is needed to establish the correct diagnosis. The diagnosis of this SBC case is achieved in conjunction with the clinical, radiographic and histological features.

The pathogenesis of SBC remains unclear. The most accepted version of the SBC is the traumatic-hemorrhagic theory, which suggests that lesions develop if intramedullary clots due to trauma do not undergo lysis or resolution [4]. In this case, the patient could not experience of previous trauma or interventions in the interested area. However, micro trauma could not be excluded.

The most commonly recommended treatment for SBC is surgical exploration of the lesion followed by curettage of the bony walls. This surgical exploration serves both as diagnostic maneuver and definitive therapy by producing bleeding in the cavity. This bleeding helps to form a clot which is eventually replaced by the bone [3]. The recurrence rate of SBC is between $20 \%$ and $30 \%$. Cases of multiple cysts or associated with florid cemento-osseous dysplasia have high recurrence ratesrespectively about $71 \%$ and $75 \%[13,14]$.

\section{Conclusion}

$\mathrm{SBC}$ is a rare pseudocyst of the jaw bone with an unclear etiology. Diagnosing SBC is a challenging since it can be achieved in conjunction with the clinical, radiographic and histological features. The most commonly recommended treatment for SBC 
is curettage after surgical exploration of the lesion. It is generally associated to a good prognosis with a low recurrent rate.

\section{Acknowledgement}

The author thanks Prof. Dr. Surapol Wiroonrak for the assistance in manuscript preparation.

\section{References}

1. Lucas C, Blum T (1929) Do all cysts of the jaws originate from the dental system. J Am Dent Assoc 16: 659-661.

2. Suei Y, Taguchi A, Tanimoto K (2007) A comparative study of simple bone cysts of the jaw and extracranial bones. Dentomaxillofac Radiol 36(3): 125-129.

3. Xanthinaki AA, Choupis KI, Tosios K, Pagkalos VA, Papanikolaou SI (2006) Traumatic bone cyst of the mandible of possible iatrogenic origin: A case report and brief review of the literature. Head Face Med 2: 40 .

4. Howe GL (1965) 'Haemorrhagic cysts' of the mandible. Br J Oral Surg 3(1): 55-76.

5. Copete MA, Kawamata A, Langlais RP (1998) Solitary bone cyst of the jaws: radiographic review of 44 cases. Oral Surg Oral Med Oral Pathol Oral Radiol Endod 85(2): 221-225.

6. Diago MP, Bielsa JMS, Marco JB, Sanz JMM (2001) Surgical treatment and follow-up of solitary bone cyst of the mandible: a report of seven cases. Br J Oral Maxillofac Surg 39(3): 221-223.
7. Regezi JA, Sciubba JJ (1999) Oral Pathology: Clinical Pathologic Correlations. In: Regezi JA, Sciubba JJ (eds.), Oral Pathology. (4 $\left.4^{\text {th }} e d n\right)$, WB Saunders, Philadelphia, Pennsylvania, USA, pp. 310-312.

8. Sathyan P, Joseph TI, Jacob G (2015) Traumatic Bone Cyst of the Jaws: A Report of Two Cases and Review. Oral Maxillofac Pathol J 6(1): 589593.

9. Forssell K, Forssell H, Happonen RP, Neva M (1988) Simple bone cyst. Review of the literature and analysis of 23 cases. Int J Oral Maxillofac Surg 17(1): 21-24.

10. Neves A, Migliari DA, Sugaya NN, de Sousa SO (2001) Traumatic bone cyst: report of two cases and review of the literature. Gen Dent 49(3): 291-295.

11. Honer K, Forman GH (1988) Atypical simple bone cysts of the jaws: a possible association with benign fibro-osseous (cemental) lesions of the jaws. Clin Radiol 39(1): 59-63.

12. Wakasa T, Kawai N, Aiga H, Kishi K (2002) Management of florid cemento-osseous dysplasia of the mandible producing solitary bone cyst: report of a case. J Oral Maxillofac Surg 60(7): 832-835.

13. Suei Y, Taguchi A, Tanimoto K (2007) Simple bone cyst of the jaws: evaluation of treatment outcome by review of 132 cases. J Oral Maxillofac Surg 65(5): 918-923.

14. Panneerselvam E, Panneerselvam K, Chanrashekar SS (2014) Solitary bone cysts-A rare occurrence with bilaterally symmetrical presentation. J Oral Maxillofac Pathol 18(3): 481.

\begin{tabular}{l} 
Your next submission with Juniper Publishers \\
will reach you the below assets \\
- Quality Editorial service \\
- Swift Peer Review \\
- Reprints availability \\
- E-prints Service \\
- Manuscript Podcast for convenient understanding \\
- Global attainment for your research \\
- Manuscript accessibility in different formats \\
( Pdf, E-pub, Full Text, Audio) \\
- Unceasing customer service \\
Track the below URL for one-step submission \\
https://juniperpublishers.com/online-submission.php \\
\hline
\end{tabular}

